Journal of Plant Production

Journal homepage: www.jpp.mans.edu.eg

Available online at: www.jpp.journals.ekb.eg

\title{
Effect of Foliar Spray with Licorice Root Extract on Production and Quality of Egyptian and Chinese Garlic
}

\author{
Hamam, M. A $^{1^{*}}$; Y.M.M². Moustafa; M.A.M³ . Ali and Asmaa S.H³ . Saleh \\ ${ }^{1}$ Vegetable Department, Faculty of Agriculture, Assuit University, Assuit, Egypt. \\ ${ }^{2}$ Horticulture Department, Faculty of Agriculture, Minia University, Minia, Egypt. \\ ${ }^{3}$ Horticulture Department, Faculty of Agriculture, New Valley University, Kharja, New Valley, Egypt.
}



Keywords: Garlic (Allium sativum L.), licorice (Glycyrrhiza glabra) root extract, yield components.

\section{INTRODUCTION}

Garlic (Allium sativum L.) is an important edible bulbous crop belonging to the family Alliaceae. It is the second most widely cultivated after onion and has been used throughout history for culinary and medicinal purposes , Garlic is grown worldwide in all temperate to subtropical and tropical hilly areas as an important spice and medicinal plant (Pandey, 2012).

Garlic has higher nutritive value especially Allicin of garlic which has antibacterial properties (Al-Otayk et al., 2009 and Sterling and Eagling, 1997) In addition, garlic is widely used in all households throughout the year. According to Amagase et al., (2001) and Iciek et al., (2009), the unique flavor and health-promoting functions of garlic are generally attributed to its rich content of sulfurcontaining compounds such as alliin, g-glutamylcysteine, and their derivatives. Processing a fresh and intact garlic bulbs by crushing, grinding, or cutting induces the release of the vacuolar enzyme alliinase, which quickly catalyzes allien to allicin. Allicin is a very unstable compound, soon rearranged and transformed into numerous lipid-soluble sulfur-containing byproducts, mostly diallyl disulfide but also diallyl sulfide , diallyl trisulfide, allylmethyl trisulfide, and diallyl tetrasulfide (Iciek et al., 2009).

Clinically, garlic has been evaluated for lowering blood pressure, cholesterol, and glucose concentration, as well as for the prevention of arteriosclerosis and cancer (Tsai et al., 2012). In addition, the biological activities of garlic, including antibacterial, antithrombotic, antioxidant, immunomodulatory, and antidiabetic actions and modulation of drug metabolism, have been extensively investigated (Gad El-hak et al., 2012; Tsai et al., 2012).
Extract of licorice roots (Glycyrrhiza glabra) contain some compounds, which have similar effects to that of growth promoters, a wide range of minerals (calcium, potassium, magnesium, iron, zinc, phosphorus), amino acids (alanine, lysine, arginine), vitamins (B1, B2, B6), and in addition; carbohydrate and nitrogen (Moses et al., 2002; AlAjeeli, 2005; Sabry et al., 2009). It also contains mevalonic acid used in gibberellins synthesis (Al-Marsoumi, 1999).

So, the aim of this study was to investigate the effect licorice root extract on Egyptian and Chinese garlic growth behavior in poor soils, production of bulbs, and chemical compositions of bulbs.

\section{MATERIALS AND METHODS}

Description of the experiments site:

Tow field experiment were conducted during two successive winter seasons of 2018/2019 and 2019/2020. These experiments were conducted at the Agricultural Research Farm of the Faculty of Agriculture, New Valley University, Kharja, Egypt (25'26’31 ${ }^{\circ} \mathrm{N}, 30^{\prime \prime} 33^{\prime} 36^{\circ} \mathrm{E}$, altitude $283 \mathrm{~m}$ ).

Generally, the experiment soil which both Egyptian and Chinese garlic cultivars were planted was not fertile and suffers lack of almost all elements essential for garlic vegetative growth and bulbs production. That was the nature of soil of experimental farm in the faculty of Agriculture, New Valley governorate.

Experimental soil analysis:

Five samples of soil were randomly taken from the experimental soil surface $(0-30 \mathrm{~cm}$ depth) before cultivation to determine the physical and chemical characteristics in according to Black (1965) and Page et al. (1982), respectively. Data of soil analysis is presented in Table 1 . 
Table 1. Soil physical and chemical analysis of the experimental soil during 2018/2019 and 2019/2020 seasons:

\begin{tabular}{lccc}
\hline \multirow{2}{*}{ Soil properties } & & \multicolumn{2}{c}{ Season } \\
\cline { 3 - 4 } & \multicolumn{2}{c}{ Particle size distribution (\%) } \\
\hline \multirow{4}{*}{ Physical } & Coarse sand & 4.92 & 5.10 \\
analysis & Fine sand & 76.34 & 75.38 \\
& Silt & 11.76 & 12.80 \\
& Clay & 6.98 & 6.72 \\
& Textural class & Sandy & Sandy \\
\hline \multirow{4}{*}{ E.C. (dsm-1 } & 1.32 & 1.24 \\
& $1: 5)$ & 8.09 & 8.19 \\
& pH (1:2.5 w/v) & & \\
& Organic matter & & 0.57 \\
Chemical & $(\%)$ & 0.57 & 5.98 \\
analysis & CaCO3 (\%) & 5.78 & 40.3 \\
& SP \% & 38.6 & 41.2 \\
& Available nutrients (mg/kg dry soil) \\
& $\mathrm{N}$ & 40.3 & 5.34 \\
& $\mathrm{P}$ & 5.10 & 86.5 \\
\hline
\end{tabular}

Experimental design and studied treatments:

The garlic cloves were planted on October $20^{\text {th }}$ and October $21^{\text {st }}$ in 2018 and 2019 seasons, respectively. The experiments were conducted in a randomized complete block design (RCBD) using split plots with 3 replicates in which the main plots were devoted for the two garlic cultivars (Egyptian and Chinese), while the sub-plots contained four concentrations of licorice root extract (control (without ), $2.5 \mathrm{~g} / \mathrm{L}, 5 \mathrm{~g} / \mathrm{L}, 7.5 \mathrm{~g} / \mathrm{L}$ ). The cloves of these two cultivars were soaked in these licorice root extract concentrations before planting. Garlic plants were sprayed with the same concentrations of licorice root extract three times at days 45, 60, 80 after planting. Each experimental plot consisted of four rows and each row was $3 \mathrm{~m}$ long and $60 \mathrm{~cm}$ wide. Garlic cloves were planted on the two sides of each row at distance of $10 \mathrm{~cm}$ apart. Soil analysis is shown in Table 1. Fertilization and control were carried out according to the recommendations of the Ministry of Agriculture.

Meteorological data:

The average air temperature and relative humidity (RH \%) in the two successive seasons were determined by the Meteorological Station of El-Kharga Oasis, New Valley Governorate, Egypt and are shown in Table 2.

Recorded data:

\section{1- Vegetative growth parameters:}

Representative samples, ten plants were randomly taken from each plot at different growth stages, i.e., 30, 60, 90 and 120 days after plantation to estimate the following characteristics:

a- Cloves germination percentage: germinated cloves after 15 and 30 days from plantation were counted and the cloves germination percentage were recorded according to the following equation:

Cloves germination percentage $=\frac{\text { Number of germinated cloves of each treatment }}{\text { Number of total planed cloves of the same treatment }} \times 100$

Preparation and application of Licorice root extract

Licorice extracts were extracted using weights of $(0.0,2.5,5.0$ and 7.5$)$ grams of dry licorice roots and were soaked in distilled water at $50^{\circ} \mathrm{C}$ for 24 hours, then it was filtered and added to the final volume of liter to reach the concentrations of (control , 2.5, 5.0 and 7.5 g/L) and were ready to be used as the four treatments of the experiments in the two successive winter seasons of 2018/2019 and 2019/2020. Licorice root extract chemical composition is described in Table 2.

Table 2 .chemical components of licorice root extraction

\begin{tabular}{lcc}
\hline Composition & \multicolumn{2}{c}{ Licorice roots } \\
\hline \multirow{4}{*}{$\mathrm{mg} / 100 \mathrm{~g} \mathrm{p} . \mathrm{w}$} & $\mathrm{Fe}$ & 18.31 \\
& $\mathrm{~K}$ & 53.14 \\
$\mathrm{Mg}$ & 54.76 \\
& $\mathrm{Ca}$ & 71.34 \\
$\mathrm{Mn}$ & 4.19 \\
$\mathrm{Cu}$ & 2.86 \\
& $\mathrm{P}$ & 846 \\
$\mathrm{~N}$ & 9.72 \\
& Carbohydrates & 10.38 \\
& Ash & 11.47 \\
& water & 8.28 \\
$\mathrm{mg} / \mathrm{g} \mathrm{p} . \mathrm{w}$ & Vitamin B1 & 32.4 \\
& Vitamin B2 & 33.7 \\
\hline
\end{tabular}

b- Plant height: It was measured in $\mathrm{cm}$ starting from the surface tip of soil to the longest leaf blade of the plant.

c- Number of leaves/plant: All visible leaves of selected plants were counted to record number of leaves per plant.

d-. Fresh weight/plant: The vegetative parts (bulbs and leaves) of selected plants of each plot were weighted to record the fresh weight per plant.

f- Dry weight/plant: The vegetative parts (bulbs and leaves) of previously selected fresh plants of each plot were oven dried at $70^{\circ} \mathrm{C}$ for 72 hours till constant weight and the dry weights were recorded.

\section{Bulb traits:}

A random sample from five plants was taken from each plot at harvesting date to determine the following parameters:

a) Average bulb fresh weight.

b) Average bulb and neck diameter.

c) Bulbing ratio: It was measured as reported by Mann (1952).

d) Bulb dry weight: one hundred grams of previously selected fresh bulbs of each plot were made into slices and oven dried at $70^{\circ} \mathrm{C}$ for 72 hours till constant weight and the dry weights were recorded.

3. Total yield:

At harvesting time, (end of April in both seasons) all garlic plants of each plot were harvested and cured for 15 days, weighed and the following data were recorded:

a. Marketable yield fed.

b. Non-marketable yield fed.

c.Total yield fed.

d. Relative total yield (\%): determined using the following equation:

$$
\text { Relative total yield }=\frac{\text { Total yield of treatment }}{\text { Total yield of control }} \times 100
$$

\section{Statistical analysis:}

All obtained data were subjected to statistical analysis of variance according to Snedecor and Cochran (1980) and means separation was carried out according to Duncan (1958) at $5 \%$ levels of probability. 
Table 3. monthly temperature at the New Valley Governorate (El-Kharga Oasis) during two growing seasons.

\begin{tabular}{|c|c|c|c|c|c|c|c|c|}
\hline \multirow{3}{*}{$\begin{array}{l}\text { Season } \\
\text { Month }\end{array}$} & \multirow{3}{*}{ Day } & \multicolumn{3}{|c|}{$2018 / 2019$} & \multicolumn{4}{|c|}{$2019 / 2020$} \\
\hline & & \multicolumn{2}{|c|}{ Temperature $^{\circ} \mathrm{C}$} & \multirow{2}{*}{$\begin{array}{c}\text { Relative } \\
\text { humidity \% }\end{array}$} & \multicolumn{2}{|c|}{ Temperature $^{\circ} \mathrm{C}$} & \multirow{2}{*}{\multicolumn{2}{|c|}{$\begin{array}{c}\text { Relative } \\
\text { humidity\% }\end{array}$}} \\
\hline & & Max. & Min. & & Max. & Min. & & \\
\hline \multirow{4}{*}{ October } & $1-10$ & 33.2 & 13.9 & 43.5 & 34.9 & 15.3 & & 42.2 \\
\hline & $11-20$ & 29.6 & 14.7 & 40.3 & 33.8 & 13.6 & & 44.5 \\
\hline & $21-31$ & 34.1 & 12.4 & 42.2 & 35.1 & 10.9 & & 45.3 \\
\hline & Average & 32.3 & 13.6 & 42 & 34.6 & 13.2 & & 44 \\
\hline \multirow{3}{*}{ November } & $1-10$ & $28-4$ & $9-6$ & $45-2$ & $30-3$ & $14-4$ & & $44-2$ \\
\hline & $11-20$ & $30-5$ & $11-8$ & $43-9$ & $29-6$ & $13-2$ & & $46-3$ \\
\hline & $21-31$ & $29-2$ & $8-2$ & $42-3$ & $24-5$ & $9-8$ & & $44-5$ \\
\hline & Average & $27-7$ & $9-8$ & $43-8$ & $28-1$ & $12-4$ & & $44-5$ \\
\hline \multirow{3}{*}{ December } & & 27.3 & 8.3 & 53.2 & 29.2 & 12.0 & & 37.9 \\
\hline & $11-20$ & 22.7 & 6.4 & 52.4 & 23.6 & 6.8 & & 42.3 \\
\hline & $21-31$ & 28.7 & 10.4 & 53.7 & 29.7 & 10.0 & & 38.8 \\
\hline \multirow{4}{*}{ January } & Average & 26.2 & 8.4 & 53.1 & 27.5 & 9.6 & & 39.7 \\
\hline & $1-10$ & 24.7 & 7.3 & 50.5 & 21.9 & 7.4 & & 54.4 \\
\hline & $11-20$ & 25.4 & 6.6 & 51.9 & 21.8 & 7.8 & & 53.8 \\
\hline & $21-31$ & 28.1 & 8.1 & 47.2 & 27.9 & 6.3 & & 43.1 \\
\hline & Average & 26.0 & 7.3 & 49.9 & 23.9 & 7.2 & & 50.4 \\
\hline \multirow{3}{*}{ February } & $1-10$ & 27.7 & 12.4 & 47.0 & 26.7 & 11.7 & & 39.3 \\
\hline & $11-20$ & 21.4 & 6.8 & 48.2 & 21.2 & 6.6 & & 38.3 \\
\hline & $20-29$ & 32.7 & 6.3 & 45.5 & 22.4 & 6.9 & & 39.1 \\
\hline \multirow{5}{*}{ March } & Average & 27.3 & 8.5 & 46.9 & 23.4 & 8.4 & & 38.9 \\
\hline & & 34.4 & 16.4 & 49.8 & 27.5 & 10.3 & & 45.4 \\
\hline & $11-20$ & 30.4 & 16.0 & 49.6 & 29.5 & 8.3 & & 37.9 \\
\hline & $21-31$ & 31.7 & 15.1 & 48.2 & 30.6 & 11.7 & & 38.9 \\
\hline & Average & 32.2 & 15.8 & 49.2 & 29.2 & 10.1 & & 40.7 \\
\hline \multirow{4}{*}{ April } & $1-10$ & 34.6 & 15.8 & 22.3 & 30.2 & 12.9 & & 31.9 \\
\hline & $11-20$ & 36.9 & 18.0 & 23.1 & 34.5 & 12.3 & & 30,0 \\
\hline & $21-31$ & 35.1 & 18.3 & 29.3 & 33.3 & 15.4 & & 28.4 \\
\hline & Average & 35.5 & 17.4 & 24.9 & 32.6 & 13.5 & & 30.1 \\
\hline \multicolumn{4}{|c|}{ TS ANI } & \multirow{4}{*}{\multicolumn{5}{|c|}{$\begin{array}{l}83.53 \% \text { in the first and second season, respectively. } \\
\text { Furthermore, the interaction between cultivars and } \\
\text { treatments showed a significant effect for garlic cloves } \\
\text { germination percentage (Table 4). }\end{array}$}} \\
\hline \multirow{3}{*}{\multicolumn{4}{|c|}{$\begin{array}{l}\text { RESULTS } \\
\text { Growth characters } \\
\text { 1.Cloves germination }\end{array}$}} & & & & & \\
\hline & & & & & & & & \\
\hline & & & & & & & & \\
\hline \multirow{3}{*}{\multicolumn{4}{|c|}{$\begin{array}{l}\text { Data in Table } 4 \text { and Fig1,2 showed that the } \\
\text { germination percentage of cloves of the Egyptian cultivar } \\
\text { were significantly higher than those of the Chinese cultivar } \\
\text { after } 15 \text { and } 30 \text { days from planting. Also, treating garlic } \\
\text { cloves before plantation of foliar spraying plants with the }\end{array}$}} & \multicolumn{5}{|c|}{$\begin{array}{l}\text { Table 4A. Effect of garlic varieties and Licorice root } \\
\text { extract on germination \% after } 15 \text { and } 30 \\
\text { days during winter seasons of } 2018 / 2019 \text { and } \\
2019 / 2020 \text {. }\end{array}$} \\
\hline & & & & \multirow{3}{*}{ Treatments } & $\begin{array}{r}\text { Germi } \\
\text { after }\end{array}$ & $\begin{array}{l}\text { tion \% } \\
\text { days }\end{array}$ & $\begin{array}{r}\text { Germi } \\
\text { after: }\end{array}$ & $\begin{array}{l}\text { lation \% } \\
30 \text { days }\end{array}$ \\
\hline & & & & & $1^{\text {st }}$ & $2^{\text {nd }}$ & $\mathbf{1}^{\mathrm{st}}$ & $2^{\text {nd }}$ \\
\hline hoth cultiv & nreviousls & (IIIIIIa & itage or & & Season & Season & Season & Season \\
\hline & piev & & & & Garl & varieties & & \\
\hline trom lower & ations to $\mathrm{h}$ & r ones. & entration & Egyptian & $77.74 \mathrm{a}$ & $78.20 \mathrm{a}$ & $93.02 \mathrm{a}$ & $93.78 \mathrm{a}$ \\
\hline of $7.5 \mathrm{~g} / \mathrm{L}$ & e root extr & crease & nination & Chinese & $71.02 \mathrm{~b}$ & $71.68 \mathrm{~b}$ & $87.51 \mathrm{~b}$ & $88.12 \mathrm{~b}$ \\
\hline percentage & ian garlic & es to $b$ & nd 96.96 & & icorice cc & entrations ( & $(\mathrm{g} / \mathrm{l})$ & \\
\hline$\%$ after 30 & om plantil & ompari & control & control & $70.96 \mathrm{~d}$ & $71.42 \mathrm{~d}$ & $86.59 \mathrm{~d}$ & $86.90 \mathrm{~d}$ \\
\hline treatment $\mathrm{v}$ & wed 89.9 & 90.28 & increased & & $72.76 \mathrm{c}$ & $73.21 \mathrm{c}$ & $89.18 \mathrm{c}$ & $89.94 \mathrm{c}$ \\
\hline that of th & 1 & & & 5 & $75.90 \mathrm{~b}$ & $76.36 \mathrm{~b}$ & $91.82 \mathrm{~b}$ & $92.41 \mathrm{~b}$ \\
\hline mat of the & entes & & & 7.5 & $77.91 \mathrm{a}$ & $78.76 \mathrm{a}$ & $93.47 \mathrm{a}$ & $94.55 \mathrm{a}$ \\
\hline
\end{tabular}

Table 4B. Effect of interaction between garlic varieties and Licorice root extract on germination \% after 15 and 30 days during winter seasons of $2018 / 2019$ and $2019 / 2020$

\begin{tabular}{lccccc}
\hline \multirow{2}{*}{ Treatments } & \multicolumn{2}{c}{ Germination \% after 15 days } & \multicolumn{2}{c}{ Germination \% after 30 days } \\
\cline { 2 - 6 } Interaction & \multicolumn{2}{c}{$\mathbf{1}^{\text {st }}$ Season } & $\mathbf{2}^{\text {nd }}$ Season & $\mathbf{1}^{\text {st }}$ Season & $\mathbf{2}^{\text {nd }}$ Season \\
\hline \multirow{4}{*}{ Egyptian } & control & $74.59 \mathrm{~cd}$ & $75.14 \mathrm{~cd}$ & $89.90 \mathrm{c}$ & $90.28 \mathrm{~d}$ \\
& 2.5 & $75.83 \mathrm{c}$ & $76.07 \mathrm{c}$ & $92.33 \mathrm{~b}$ & $92.86 \mathrm{c}$ \\
& 5 & $78.91 \mathrm{~b}$ & $79.44 \mathrm{~b}$ & $94.50 \mathrm{a}$ & $95.03 \mathrm{~b}$ \\
& 7.5 & $81.63 \mathrm{a}$ & $82.38 \mathrm{a}$ & $95.36 \mathrm{a}$ & $96.96 \mathrm{a}$ \\
\hline \multirow{2}{*}{ Chinese } & control & $67.34 \mathrm{f}$ & $67.92 \mathrm{f}$ & $83.28 \mathrm{e}$ & $83.53 \mathrm{f}$ \\
& 2.5 & $69.68 \mathrm{e}$ & $70.36 \mathrm{e}$ & $86.03 \mathrm{~d}$ & $87.02 \mathrm{e}$ \\
& 5 & $72.88 \mathrm{~d}$ & $73.28 \mathrm{~d}$ & $89.15 \mathrm{c}$ & $89.80 \mathrm{~d}$ \\
& 7.5 & $74.20 \mathrm{~cd}$ & $74.92 \mathrm{~cd}$ & $91.58 \mathrm{~b}$ & $92.15 \mathrm{c}$ \\
\hline
\end{tabular}





Fig. 1. Effect of interaction between garlic varieties and Licorice root extract on germination \% after 15 days during winter seasons of 2018/2019 and 2019/2020.
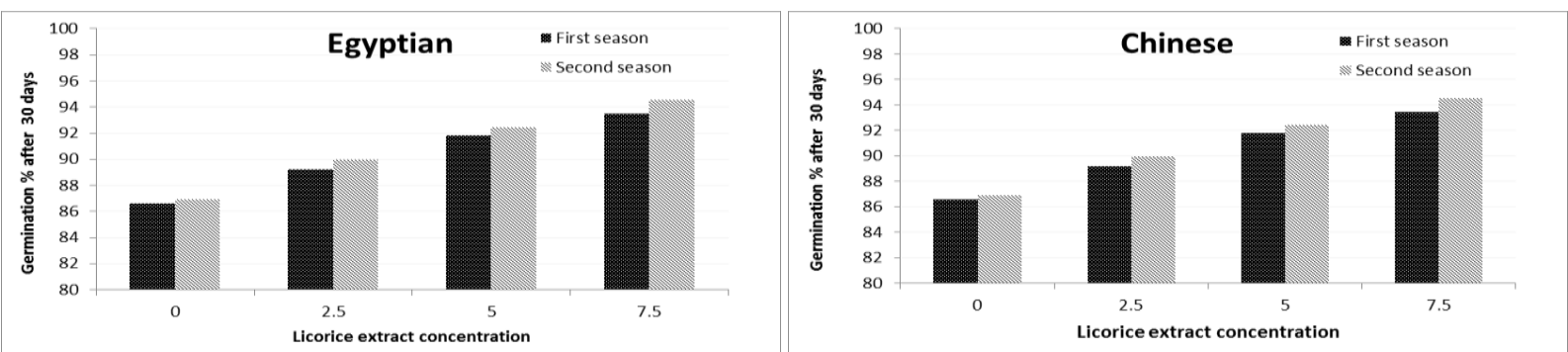

Fig. 2. Effect of interaction between garlic varieties and Licorice root extraction germination \% after 30 days during winter seasons of 2018/2019 and 2019/2020.

\section{Plant height}

This character was recorded 4 times; after 20, 60, 90, and 120 days from planting cloves of Egyptian and Chinese garlic cultivars in the soil. Data in Table 5 and Fig 3 is showing that the Egyptian cultivars recorded higher values of plant height than those of the Chinese cultivar especially at the recording time of 120 days in the two seasons (62.34, $63.33 \mathrm{~cm}$ and $53.46,54.32 \mathrm{~cm}$ ), respectively. Also, treating garlic cloves with the licorice root extract before planting increased the values of garlic plant height significantly to reach the values of 70.82 and $71.58 \mathrm{~cm}$ in the first and second seasons, respectively. Furthermore, the interaction between cultivars and treatments showed significant effects for this character as the Egyptian cultivar showed the highest values of garlic plant height in all recorded times (Table 5).

Table 5A. Effect of garlic varieties and Licorice root extract on garlic plant height at 30, 60, 90 and 120 days after planting during winter seasons of 2018/2019 and 2019/2020.

\begin{tabular}{|c|c|c|c|c|c|c|c|c|}
\hline \multirow{4}{*}{ Treatments } & \multicolumn{8}{|c|}{ Plant height (cm) } \\
\hline & \multicolumn{8}{|c|}{ Days after planting } \\
\hline & \multicolumn{2}{|c|}{30} & \multicolumn{2}{|c|}{60} & \multicolumn{2}{|c|}{90} & \multicolumn{2}{|c|}{120} \\
\hline & $\mathbf{1}^{\text {st }}$ Season & $2^{\text {nd }}$ Season & $\mathbf{1}^{\text {st }}$ Season & $2^{\text {nd }}$ Season & $\mathbf{1}^{\text {st }}$ Season & $2^{\text {nd }}$ Season & $\mathbf{1}^{\text {st }}$ Season & $2^{\text {nd }}$ Season \\
\hline \multicolumn{9}{|c|}{ Garlic varieties } \\
\hline Egyptian & $34.04 \mathrm{a}$ & $34.34 \mathrm{a}$ & $41.17 \mathrm{a}$ & $41.62 \mathrm{a}$ & $52.55 \mathrm{a}$ & $52.99 \mathrm{a}$ & $62.34 \mathrm{a}$ & $63.33 \mathrm{a}$ \\
\hline Chinese & $24.35 \mathrm{~b}$ & $24.96 \mathrm{~b}$ & $36.94 \mathrm{a}$ & $37.51 \mathrm{a}$ & $47.85 \mathrm{~b}$ & $48.53 \mathrm{~b}$ & $53.46 \mathrm{a}$ & $54.32 \mathrm{a}$ \\
\hline \multicolumn{9}{|c|}{ Licorice concentrations (g/l) } \\
\hline control & $22.83 \mathrm{~d}$ & $23.14 \mathrm{~d}$ & $29.86 \mathrm{~d}$ & $30.53 \mathrm{~d}$ & $40.83 \mathrm{~d}$ & $41.45 \mathrm{~d}$ & $45.71 \mathrm{~d}$ & $46.39 \mathrm{~d}$ \\
\hline 2.5 & $26.16 \mathrm{c}$ & $26.71 \mathrm{c}$ & $36.35 \mathrm{c}$ & $36.95 \mathrm{c}$ & $47.15 \mathrm{c}$ & $47.87 \mathrm{c}$ & $52.81 \mathrm{c}$ & $54.02 \mathrm{c}$ \\
\hline 5 & $30.90 \mathrm{~b}$ & $31.21 \mathrm{~b}$ & $42.79 \mathrm{~b}$ & $43.11 \mathrm{~b}$ & $53.32 \mathrm{~b}$ & $53.90 \mathrm{~b}$ & $62.26 \mathrm{~b}$ & $63.31 \mathrm{~b}$ \\
\hline 7.5 & $36.91 \mathrm{a}$ & $37.55 \mathrm{a}$ & $47.22 \mathrm{a}$ & $47.67 \mathrm{a}$ & $59.50 \mathrm{a}$ & $59.83 \mathrm{a}$ & $70.82 \mathrm{a}$ & $71.58 \mathrm{a}$ \\
\hline
\end{tabular}

Table 5B. Effect of interaction between garlic varieties and Licorice root extract on garlic plant height at $30,60,90$ and 120 days after transplanting during winter seasons of 2018/2019 and 2019/2020.

\begin{tabular}{|c|c|c|c|c|c|c|c|c|c|}
\hline \multirow{4}{*}{ Treatments } & & \multicolumn{8}{|c|}{ Plant height (cm) } \\
\hline & & \multicolumn{8}{|c|}{ Days after planting } \\
\hline & & \multicolumn{2}{|c|}{30} & \multicolumn{2}{|c|}{60} & \multicolumn{2}{|c|}{90} & \multicolumn{2}{|c|}{120} \\
\hline & & $\mathbf{1}^{\text {st }}$ Season & $2^{\text {nd }}$ Season & $1^{\text {st }}$ Season & $2^{\text {nd }}$ Season & $1^{\text {st }}$ Season & $2^{\text {nd }}$ Season & $\mathbf{1}^{\text {st }}$ Season & $2^{\text {nd }}$ Season \\
\hline \multicolumn{10}{|c|}{ Interaction } \\
\hline \multirow{4}{*}{ Egyptian } & control & $26.97 \mathrm{~cd}$ & $27.45 \mathrm{~cd}$ & $33.85 \mathrm{e}$ & $34.90 \mathrm{e}$ & 41.92 de & $42.83 \mathrm{de}$ & $48.96 \mathrm{~cd}$ & $49.88 \mathrm{~d}$ \\
\hline & 2.5 & $30.39 \mathrm{c}$ & $30.69 \mathrm{bc}$ & $38.98 \mathrm{~d}$ & $39.16 \mathrm{~d}$ & $49.45 \mathrm{c}$ & $49.75 \mathrm{c}$ & $57.85 \mathrm{bc}$ & $59.15 \mathrm{c}$ \\
\hline & 5 & $35.92 \mathrm{~b}$ & $36.04 \mathrm{~b}$ & $43.95 \mathrm{bc}$ & $44.16 \mathrm{bc}$ & $55.93 \mathrm{~b}$ & $56.21 \mathrm{~b}$ & $66.58 \mathrm{~b}$ & $67.93 \mathrm{~b}$ \\
\hline & 7.5 & $42.89 \mathrm{a}$ & $43.19 \mathrm{a}$ & $47.90 \mathrm{a}$ & $48.25 \mathrm{a}$ & $62.92 \mathrm{a}$ & $63.16 \mathrm{a}$ & $75.96 \mathrm{a}$ & $76.38 \mathrm{a}$ \\
\hline \multirow{4}{*}{ Chinese } & control & $18.69 \mathrm{e}$ & $18.83 \mathrm{e}$ & $25.86 \mathrm{f}$ & $26.16 \mathrm{f}$ & $39.74 \mathrm{e}$ & $40.06 \mathrm{e}$ & $42.46 \mathrm{~d}$ & $42.90 \mathrm{e}$ \\
\hline & 2.5 & $21.93 \mathrm{de}$ & $22.73 \mathrm{de}$ & $33.72 \mathrm{e}$ & $34.73 \mathrm{e}$ & $44.85 \mathrm{~d}$ & $45.98 \mathrm{~d}$ & $47.76 \mathrm{~cd}$ & $48.90 \mathrm{~d}$ \\
\hline & 5 & $25.88 \mathrm{~cd}$ & $26.38 \mathrm{~cd}$ & $41.63 \mathrm{~cd}$ & $42.05 \mathrm{~cd}$ & $50.71 \mathrm{c}$ & $51.58 \mathrm{c}$ & $57.93 \mathrm{bc}$ & $58.70 \mathrm{c}$ \\
\hline & 7.5 & $30.92 \mathrm{c}$ & $31.92 \mathrm{bc}$ & $46.55 \mathrm{ab}$ & $47.10 \mathrm{ab}$ & $56.09 \mathrm{~b}$ & $56.50 \mathrm{~b}$ & $65.69 \mathrm{~b}$ & $66.79 \mathrm{~b}$ \\
\hline
\end{tabular}




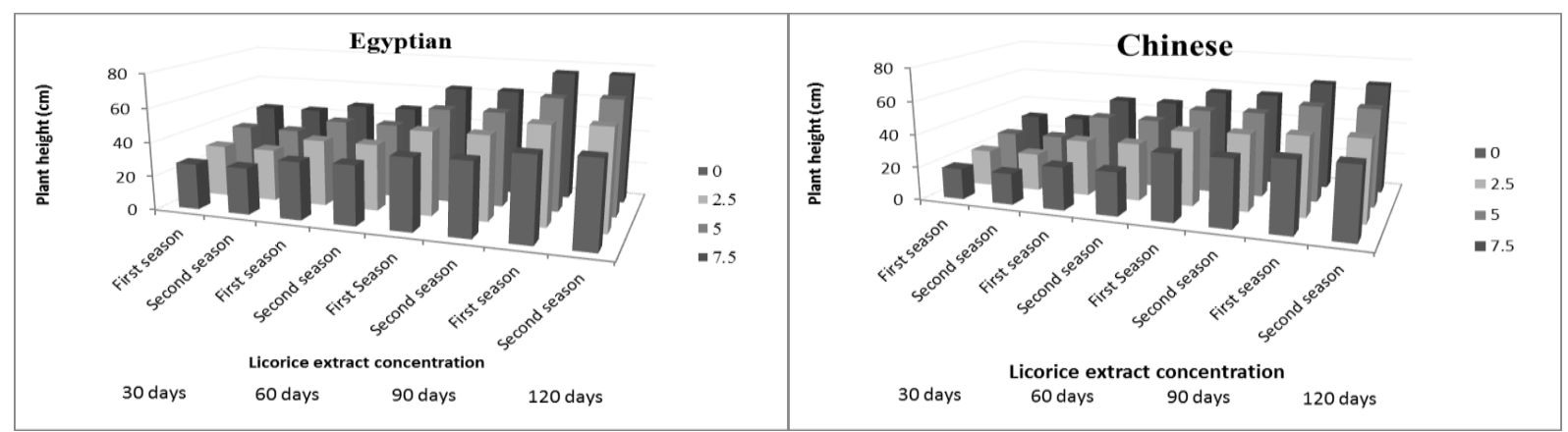

Fig. 3. Effect of interaction between garlic varieties and Licorice root extract on garlic plant height at 30, 60,90 and 120 days after planting during winter seasons of 2018/2019 and 2019/2020.

3.Number of leaves/plant

Table 6 and Fig 4 is describing the total number of leaves/plant in studied garlic cultivars, treating their cloves or non-treating with licorice root extract and data showed that the Egyptian cultivar had higher number of leaves than the Chinese cultivar. Moreover, the treatments with licorice root extract significantly increased this number of leaves/plant with increasing the treatment concentration at the studied ages; 30, 60, 90, and 120 days of cloves plantation. The treatment with the highest used $(7.5 \mathrm{~g} / \mathrm{L})$ concentration of licorice root extract increased the total number of leaves/plant up to 9.70 and 9.84 in the two seasons comparing to the non-treated clove (6.61 and 6.75), respectively. The interaction between cultivars and treatments had a significant effect on this character (Table $6)$.

Table 6A. Effect of garlic varieties and Licorice root extract on garlic number of leaves/plant at 30, 60,90 and 120 days after planting during winter seasons of 2018/2019 and 2019/2020.

\begin{tabular}{|c|c|c|c|c|c|c|c|c|}
\hline \multirow{4}{*}{ Treatments } & \multicolumn{8}{|c|}{ Number of leaves/plant } \\
\hline & \multicolumn{8}{|c|}{ Days after planting } \\
\hline & \multicolumn{2}{|c|}{30} & \multicolumn{2}{|c|}{60} & \multicolumn{2}{|r|}{90} & \multicolumn{2}{|c|}{120} \\
\hline & $\mathbf{1}^{\text {st }}$ Season & $2^{\text {nd }}$ Season & 1 $^{\text {st Season }}$ & $2^{\text {nd }}$ Season & $\mathbf{1}^{\text {stSeason }}$ & $2^{\text {nd }}$ Season & $\mathbf{1}^{\text {st }}$ Season & $2^{\text {nd }}$ Season \\
\hline \multicolumn{9}{|c|}{ Garlic varieties } \\
\hline Egyptian & $3.83 \mathrm{a}$ & $3.91 \mathrm{a}$ & $5.25 \mathrm{a}$ & $5.36 \mathrm{a}$ & $6.43 \mathrm{a}$ & $6.54 \mathrm{a}$ & $8.05 \mathrm{a}$ & $8.22 \mathrm{a}$ \\
\hline Chinese & $3.40 \mathrm{a}$ & $3.49 \mathrm{a}$ & $4.61 \mathrm{~b}$ & $4.76 \mathrm{~b}$ & $6.12 b$ & $6.25 \mathrm{a}$ & $7.72 \mathrm{a}$ & $7.86 \mathrm{a}$ \\
\hline \multicolumn{9}{|c|}{ Licorice concentrations $(\mathrm{g} / \mathrm{l})$} \\
\hline$\overline{0}$ & $2.90 \mathrm{c}$ & $2.99 \mathrm{c}$ & $3.97 \mathrm{~d}$ & $4.10 \mathrm{~d}$ & $5.23 \mathrm{c}$ & $5.28 \mathrm{~d}$ & $6.61 \mathrm{c}$ & $6.75 \mathrm{~d}$ \\
\hline 2.5 & $3.16 \mathrm{c}$ & $3.22 \mathrm{c}$ & $4.56 \mathrm{c}$ & $4.65 \mathrm{c}$ & $5.56 \mathrm{c}$ & $5.73 \mathrm{c}$ & $7.10 \mathrm{c}$ & $7.20 \mathrm{c}$ \\
\hline 5 & $3.85 \mathrm{~b}$ & $3.94 \mathrm{~b}$ & $5.13 \mathrm{~b}$ & $5.25 \mathrm{~b}$ & $6.55 \mathrm{~b}$ & $6.66 \mathrm{~b}$ & $8.12 \mathrm{~b}$ & $8.38 \mathrm{~b}$ \\
\hline 7.5 & $4.55 \mathrm{a}$ & $4.66 \mathrm{a}$ & $6.06 \mathrm{a}$ & $6.26 \mathrm{a}$ & $7.76 \mathrm{a}$ & $7.91 \mathrm{a}$ & $9.70 \mathrm{a}$ & $9.84 \mathrm{a}$ \\
\hline
\end{tabular}

Table 6B. Effect of interaction between garlic varieties and Licorice root extract on garlic Number of leaves/plant of garlic plants at 30, 60, 90 and 120 days after planting during winter seasons of 2018/2019 and 2019/2020.

\begin{tabular}{|c|c|c|c|c|c|c|c|c|c|}
\hline \multirow{4}{*}{ Treatments } & & \multicolumn{8}{|c|}{ Number of leaves/plant } \\
\hline & & \multicolumn{8}{|c|}{ Days after planting } \\
\hline & & \multicolumn{2}{|c|}{30} & \multicolumn{2}{|c|}{60} & \multicolumn{2}{|c|}{90} & \multicolumn{2}{|c|}{120} \\
\hline & & $1^{\text {st }}$ Season & $2^{\text {nd }}$ Season & $\mathbf{1}^{\text {st }}$ Season & $2^{\text {nd }}$ Season & $1^{\text {st }}$ Season & $2^{\text {nd }}$ Season & $\mathbf{1}^{\text {st }}$ Season & $2^{\text {nd }}$ Season \\
\hline \multirow{5}{*}{ Egyptian } & & & & & Interaction & & & & \\
\hline & 0 & $3.14 \mathrm{bc}$ & $3.22 \mathrm{~cd}$ & $4.29 \mathrm{e}$ & $4.40 \mathrm{~d}$ & $5.33 \mathrm{~d}$ & $5.40 \mathrm{de}$ & $6.83 \mathrm{~d}$ & $6.93 \mathrm{de}$ \\
\hline & 2.5 & $3.26 \mathrm{bc}$ & $3.33 \mathrm{~cd}$ & $4.80 \mathrm{de}$ & $4.86 \mathrm{~cd}$ & $5.66 \mathrm{~cd}$ & $5.78 \mathrm{~d}$ & $7.28 \mathrm{~cd}$ & $7.33 \mathrm{~d}$ \\
\hline & 5 & $4.20 \mathrm{a}$ & $4.21 \mathrm{~b}$ & $5.33 \mathrm{bc}$ & $5.46 \mathrm{~b}$ & $6.93 \mathrm{~b}$ & $7.06 \mathrm{~b}$ & $8.33 \mathrm{~b}$ & $8.66 \mathrm{~b}$ \\
\hline & 7.5 & $4.73 \mathrm{a}$ & $4.88 \mathrm{a}$ & $6.60 \mathrm{a}$ & $6.73 \mathrm{a}$ & $7.80 \mathrm{a}$ & $7.93 \mathrm{a}$ & $9.75 \mathrm{a}$ & $9.98 \mathrm{a}$ \\
\hline \multirow{4}{*}{ Chinese } & 0 & $2.67 \mathrm{c}$ & $2.77 \mathrm{~d}$ & $3.65 \mathrm{f}$ & $3.80 \mathrm{e}$ & $5.13 \mathrm{~d}$ & $5.16 \mathrm{e}$ & $6.40 \mathrm{~d}$ & $6.56 \mathrm{e}$ \\
\hline & 2.5 & $3.06 \mathrm{bc}$ & $3.11 \mathrm{~cd}$ & $4.33 \mathrm{e}$ & $4.43 \mathrm{~d}$ & $5.46 \mathrm{~d}$ & $5.69 \mathrm{~d}$ & $6.92 \mathrm{~d}$ & $7.06 \mathrm{de}$ \\
\hline & 5 & $3.49 \mathrm{~b}$ & $3.66 \mathrm{c}$ & $4.93 \mathrm{~cd}$ & $5.03 \mathrm{c}$ & $6.16 \mathrm{c}$ & $6.26 c$ & $7.91 \mathrm{bc}$ & $8.10 \mathrm{c}$ \\
\hline & 7.5 & $4.37 \mathrm{a}$ & $4.44 \mathrm{ab}$ & $5.53 b$ & $5.80 \mathrm{~b}$ & $7.73 \mathrm{a}$ & $7.90 \mathrm{a}$ & $9.65 \mathrm{a}$ & 9.71 \\
\hline
\end{tabular}

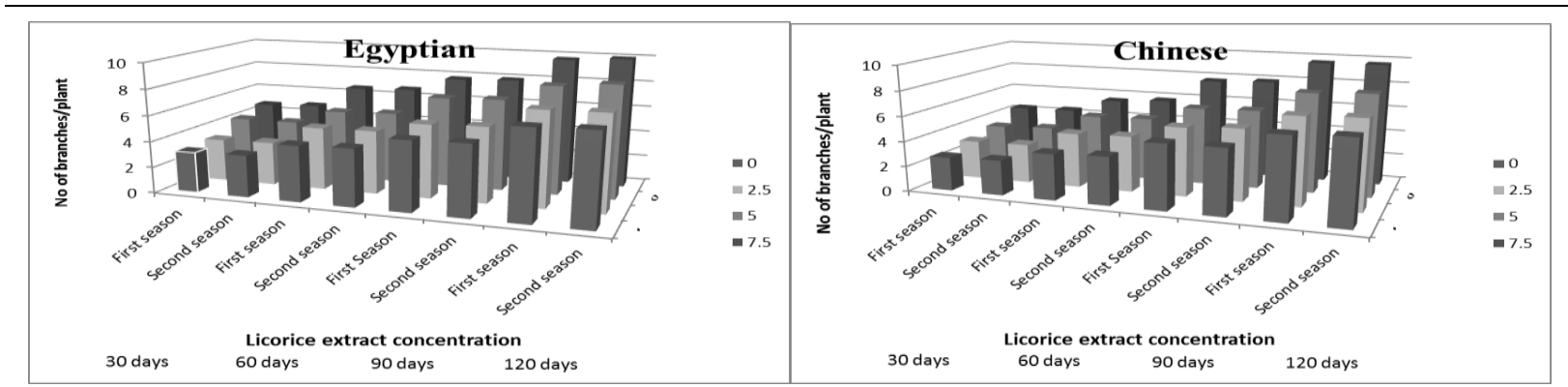

Fig. 4. Effect of interaction between garlic varieties and Licorice root extract on garlic Number of leaves/plant of garlic plants at 30, 60, 90 and 120 days after planting during winter seasons of 2018/2019 and 2019/2020 


\section{Plant fresh weight}

This character showed that plants of the Egyptian cultivar had higher values of fresh weight at the age of 120 days from planting garlic cloves (76.18 and $77.08 \mathrm{~g}$ ) than that of the Chinese cultivar (66.43 and $67.22 \mathrm{~g}$ ) under the conditions of these experiments (soil properties are not suitable enough for garlic production) although the values were almost similar along with the growing seasons (after 30, 60, and 90 days from planting garlic cloves). Treating garlic cloves before plantation and spraying the plants with licorice root extract significantly these values to reach 92.95 and $95.07 \mathrm{~g}$ after 120 days from planting the cloves in the first and second seasons, respectively (Table 7). The effect of the interaction of cultivars and treatments was higher in the Egyptian cultivar (99.93 and $101.91 \mathrm{~g}$ ) than that of the Chinese cultivar (85.96 and $88.24 \mathrm{~g}$ ) in the first and second seasons, respectively as shown in Table 7 and Fig 5.

Table 7A. Effect of garlic varieties and Licorice root extract on garlic Fresh weight (bulb + leaves)/plant (g) at 30, 60, 90 and 120 days after transplanting during winter seasons of 2018/2019 and 2019/2020. Fresh weight (bulb + leaves)/plant (g)

\begin{tabular}{|c|c|c|c|c|c|c|c|c|}
\hline \multirow{3}{*}{ Treatments } & \multicolumn{8}{|c|}{ Days after planting } \\
\hline & \multicolumn{2}{|c|}{30} & \multicolumn{2}{|c|}{60} & \multicolumn{2}{|c|}{90} & \multicolumn{2}{|c|}{120} \\
\hline & $\begin{array}{c}1^{\text {st }} \\
\text { Season }\end{array}$ & $\begin{array}{c}2^{\text {nd }} \\
\text { Season }\end{array}$ & $\begin{array}{c}1^{\text {st }} \\
\text { Season }\end{array}$ & $\begin{array}{c}2^{\text {nd }} \\
\text { Season }\end{array}$ & $\begin{array}{c}1^{\text {st }} \\
\text { Season }\end{array}$ & $\begin{array}{c}2^{\text {nd }} \\
\text { Season }\end{array}$ & $\begin{array}{c}1^{\text {st }} \\
\text { Season }\end{array}$ & $\begin{array}{c}2^{\text {nd }} \\
\text { Season }\end{array}$ \\
\hline \multicolumn{9}{|c|}{ Garlic varieties } \\
\hline Egyptian & $8.30 \mathrm{a}$ & $8.47 \mathrm{a}$ & $17.58 \mathrm{a}$ & $18.19 \mathrm{a}$ & $36.95 \mathrm{a}$ & $37.44 \mathrm{a}$ & $76.18 \mathrm{a}$ & $77.08 \mathrm{a}$ \\
\hline Chinese & $7.72 \mathrm{a}$ & $8.11 \mathrm{a}$ & $17.20 \mathrm{a}$ & $17.42 \mathrm{a}$ & $36.23 \mathrm{a}$ & $36.40 \mathrm{a}$ & $66.43 \mathrm{~b}$ & $67.22 \mathrm{~b}$ \\
\hline \multicolumn{9}{|c|}{ Licorice concentrations $(\mathrm{g} / \mathrm{l})$} \\
\hline 0 & $5.93 \mathrm{c}$ & $6.18 \mathrm{~d}$ & $14.92 \mathrm{~d}$ & $15.28 \mathrm{~d}$ & $25.59 \mathrm{~d}$ & $25.91 \mathrm{~d}$ & $54.38 \mathrm{~d}$ & $54.65 \mathrm{~d}$ \\
\hline 2.5 & $7.37 \mathrm{bc}$ & $7.91 \mathrm{c}$ & $16.61 \mathrm{c}$ & $17.19 \mathrm{c}$ & $31.69 \mathrm{c}$ & $31.78 \mathrm{c}$ & $63.95 \mathrm{c}$ & $64.26 \mathrm{c}$ \\
\hline 5 & $8.56 \mathrm{ab}$ & $8.78 \mathrm{~b}$ & $18.14 \mathrm{~b}$ & $18.62 \mathrm{~b}$ & $41.00 \mathrm{~b}$ & $41.76 \mathrm{~b}$ & $73.94 \mathrm{~b}$ & $74.63 \mathrm{~b}$ \\
\hline 7.5 & $10.20 \mathrm{a}$ & $10.30 \mathrm{a}$ & $19.90 \mathrm{a}$ & $20.11 \mathrm{a}$ & $48.08 \mathrm{a}$ & $48.23 \mathrm{a}$ & $92.95 \mathrm{a}$ & $95.07 \mathrm{a}$ \\
\hline
\end{tabular}

Table 7B. Effect of interaction between garlic varieties and Licorice root extract on garlic Fresh weight (bulb + leaves)/plant (g) at 30, 60, 90 and 120 days after plantation during winter seasons of 2018/2019 and 2019/2020.

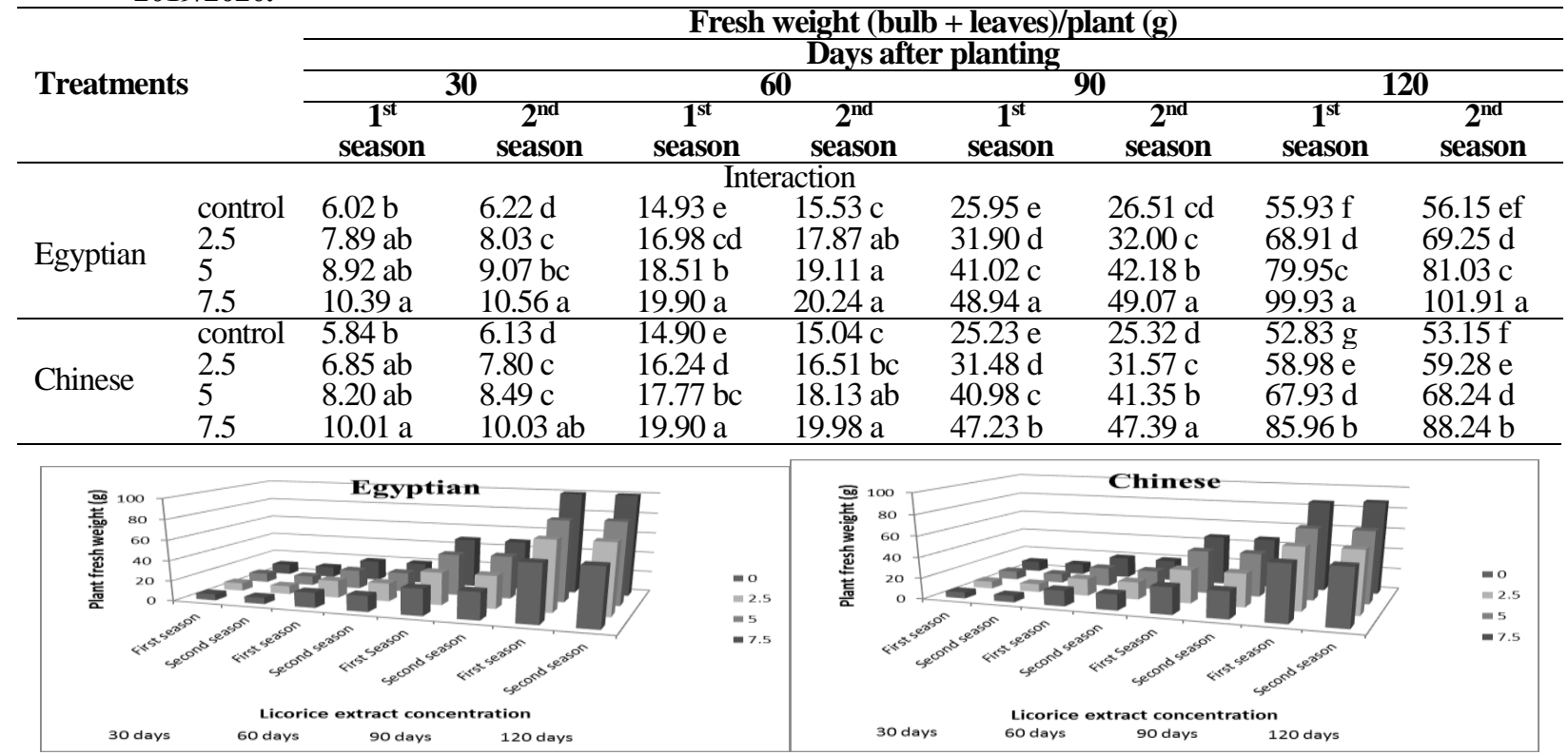

Fig. 5. Effect of interaction between garlic varieties and Licorice root extract on garlic Fresh weight (bulb + leaves)/plant (g) at 30, 60, 90 and 120 days after plantation during winter seasons of 2018/2019 and 2019/2020.

\section{Bulb characters}

\section{Bulb fresh weight (g) and bulb dry weight $(\mathrm{g})$}

This character was significantly affected by garlic cultivars and licorice roots extract treatments as described in Table 8 and Fig 6. The Egyptian cultivar produced bulbs with higher fresh weight values $(69.98$ and $70.59 \mathrm{~g})$ than those of the Chinese one $(66.26$ and $66.83 \mathrm{~g})$ and these differences were significant in the second season. Moreover, treating garlic cloves or plants with licorice roots extract significantly increased bulbs fresh weight from 50.59 and $51.21 \mathrm{~g}$ (control) to 88.82 and $89.28 \mathrm{~g}(7.5 \mathrm{~g} / \mathrm{L}$ of the treatment) in the first and second seasons, respectively. Regarding the interaction between cultivars and treatments, the Egyptian cultivar responded to the licorice roots extract treatment more than the Chinese cultivar and gave bulbs with higher fresh weight values especially with the treatment of $7.5 \mathrm{~g} / \mathrm{L}(92.80$ and $93.71 \mathrm{~g}$ ) for the Egyptian cultivar and $(84.84$ and $84.85 \mathrm{~g})$ in the first and second seasons, respectively. Bulbs dry weight character was somehow similar to bulb fresh weight character as shown in Table 8 and Fig 6. 
Table 8A. Effect of garlic varieties and licorice root extract on bulb fresh weight, bulb diameter, bulbing ratio and bulb dry matter of garlic plants at harvesting date during winter seasons of 2018/2019 and 2019/2020

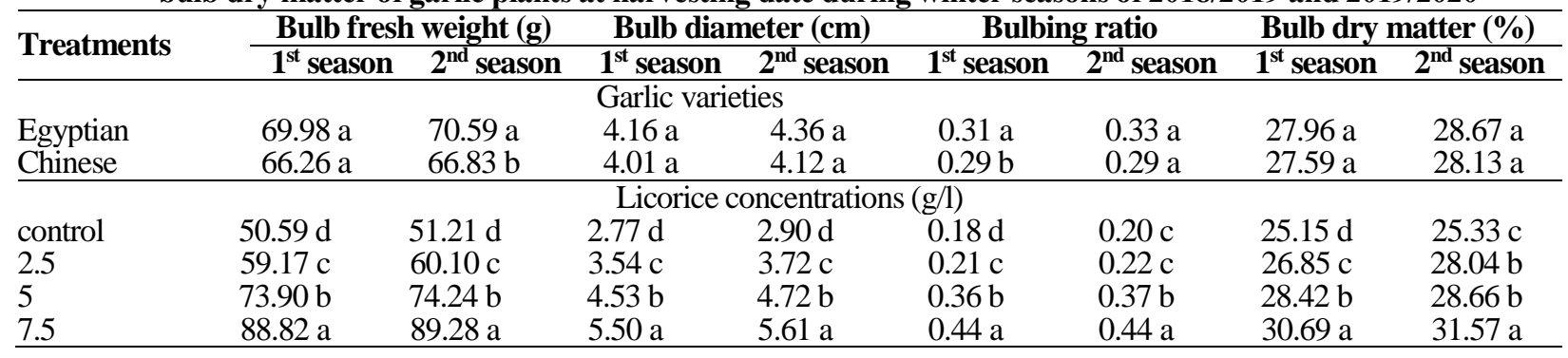

Table 8B.Effect of interaction between garlic varieties and licorice root extract on bulb fresh weight, bulb diameter, bulbing ratio and bulb dry matter of garlic plants at harvesting date during winter seasons of 2018/2019 and 2019/2020.

\begin{tabular}{|c|c|c|c|c|c|c|c|c|c|}
\hline \multirow{2}{*}{ Treatments } & & \multicolumn{2}{|c|}{ Bulb fresh weight (g) } & \multicolumn{2}{|c|}{ Bulb diameter $(\mathrm{cm})$} & \multicolumn{2}{|c|}{ Blubbing ratio } & \multicolumn{2}{|c|}{ Bulb dry matter(\%) } \\
\hline & & $\mathbf{1}^{\text {st }}$ season & $2^{\text {nd }}$ season & $1^{\text {st }}$ season & $2^{\text {nd }}$ season & $1^{\text {st }}$ season & $2^{\text {nd }}$ season & $\mathbf{1}^{\text {st }}$ season & $2^{\text {nd }}$ season \\
\hline \multicolumn{10}{|c|}{ Garlic varieties licorice concentrations (g/l) } \\
\hline \multirow{4}{*}{ Egyptian } & 0 & $51.49 \mathrm{~d}$ & $51.93 \mathrm{~d}$ & $2.78 \mathrm{~d}$ & $2.98 \mathrm{~d}$ & $0.19 \mathrm{~d}$ & $0.22 \mathrm{~cd}$ & $25.36 \mathrm{~d}$ & $25.36 \mathrm{~b}$ \\
\hline & 2.5 & $59.61 \mathrm{~d}$ & $60.59 \mathrm{~cd}$ & $3.64 \mathrm{c}$ & $3.88 \mathrm{c}$ & $0.23 \mathrm{c}$ & $0.25 \mathrm{c}$ & $26.90 \mathrm{c}$ & $28.72 \mathrm{ab}$ \\
\hline & 5 & $76.02 \mathrm{c}$ & $76.11 \mathrm{~b}$ & $4.67 \mathrm{~b}$ & $4.82 \mathrm{~b}$ & $0.37 \mathrm{~b}$ & $0.39 \mathrm{~b}$ & $28.69 \mathrm{~b}$ & $29.01 \mathrm{ab}$ \\
\hline & 7.5 & $92.80 \mathrm{a}$ & $93.71 \mathrm{a}$ & $5.58 \mathrm{a}$ & $5.75 \mathrm{a}$ & $0.45 \mathrm{a}$ & $0.46 \mathrm{a}$ & $30.91 \mathrm{a}$ & $31.58 \mathrm{a}$ \\
\hline \multirow{4}{*}{ Chinese } & 0 & $49.68 \mathrm{~d}$ & $50.49 \mathrm{~d}$ & $2.76 \mathrm{~d}$ & $2.82 \mathrm{~d}$ & $0.18 \mathrm{~d}$ & $0.18 \mathrm{~d}$ & $24.95 \mathrm{~d}$ & $25.29 \mathrm{~b}$ \\
\hline & 2.5 & $58.73 \mathrm{~d}$ & $59.61 \mathrm{~cd}$ & $3.45 \mathrm{c}$ & $3.57 \mathrm{c}$ & $0.19 \mathrm{~d}$ & $0.20 \mathrm{~d}$ & $26.80 \mathrm{c}$ & $27.36 \mathrm{ab}$ \\
\hline & 5 & $71.78 \mathrm{c}$ & $72.37 \mathrm{bc}$ & $4.40 \mathrm{~b}$ & $4.62 \mathrm{~b}$ & $0.36 \mathrm{~b}$ & $0.36 \mathrm{~b}$ & $28.16 b$ & $28.31 \mathrm{ab}$ \\
\hline & 7.5 & $84.84 \mathrm{~b}$ & $84.85 \mathrm{ab}$ & $5.43 \mathrm{a}$ & $5.46 \mathrm{a}$ & $0.42 \mathrm{a}$ & $0.43 \mathrm{a}$ & $30.48 \mathrm{a}$ & $31.56 \mathrm{a}$ \\
\hline
\end{tabular}

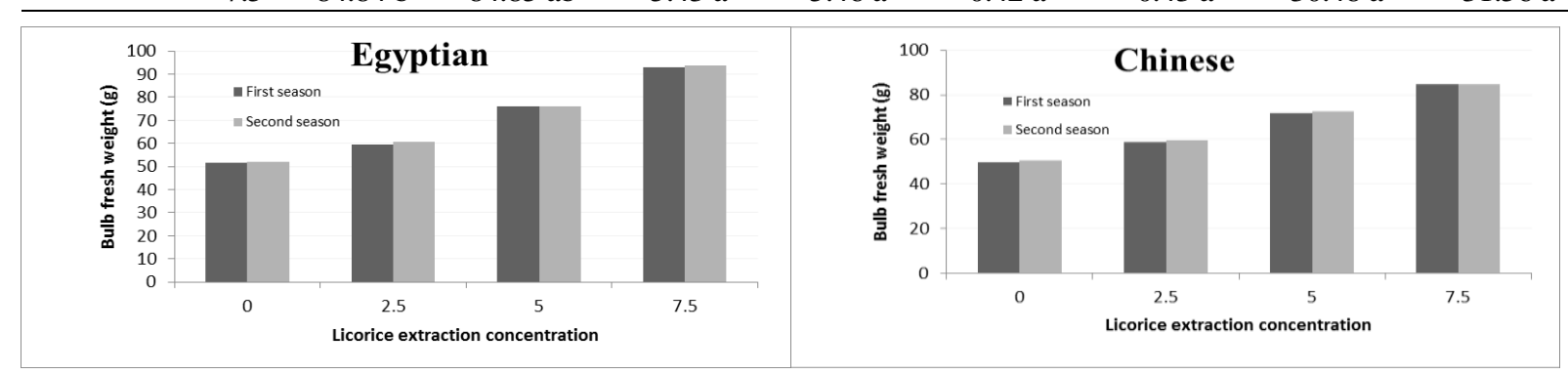

Fig. 6. Effect of interaction between garlic varieties and licorice root extract on bulb fresh weight of garlic plants at harvesting date during winter seasons of 2018/2019 and 2019/2020.

2. Bulb diameter (cm) and bulbing ratio

Bulb diameter was almost similar in both

Egyptian and Chinese cultivars in the control treatment Table (8) and Fig 7 but treating garlic cloves and plants with licorice roots extract increased bulbs diameter from 2.77 and $2.90 \mathrm{~cm}$ (control " 0.0 " treatment) to 5.50 and $5.61 \mathrm{~cm}(7.5 \mathrm{~g} / \mathrm{L}$ treatment). The effect of interaction

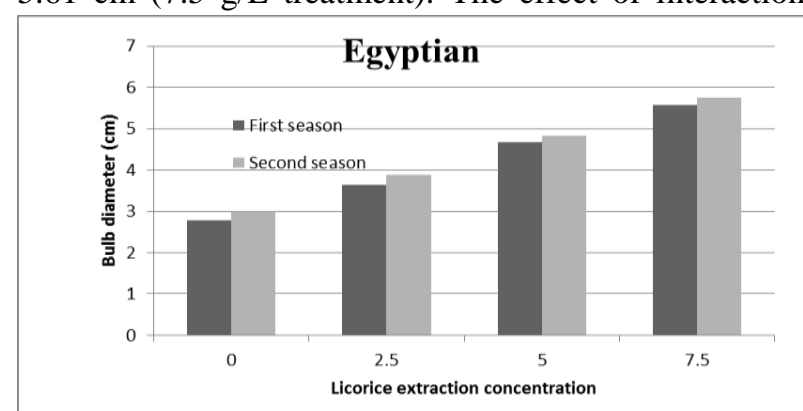

between treatments and cultivars on this character was insignificant (table 8). Regarding the bulbing ratio, it took the same trend like bulb diameter as neck diameter did not differ significantly between the used two cultivars but as the neck diameter increased by licorice treatment the bulbing ratio increased Table (8) and Fig $8-9$.

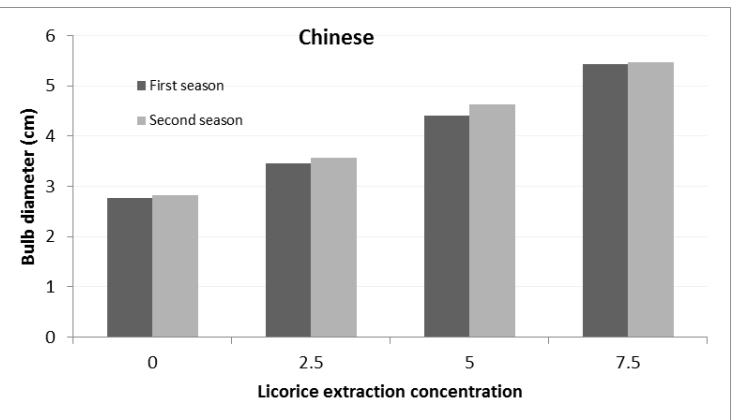

Fig. 7. Effect of interaction between garlic varieties and licorice root extract on bulb diameter of garlic plants at harvesting date during winter seasons of 2018/2019 and 2019/2020 

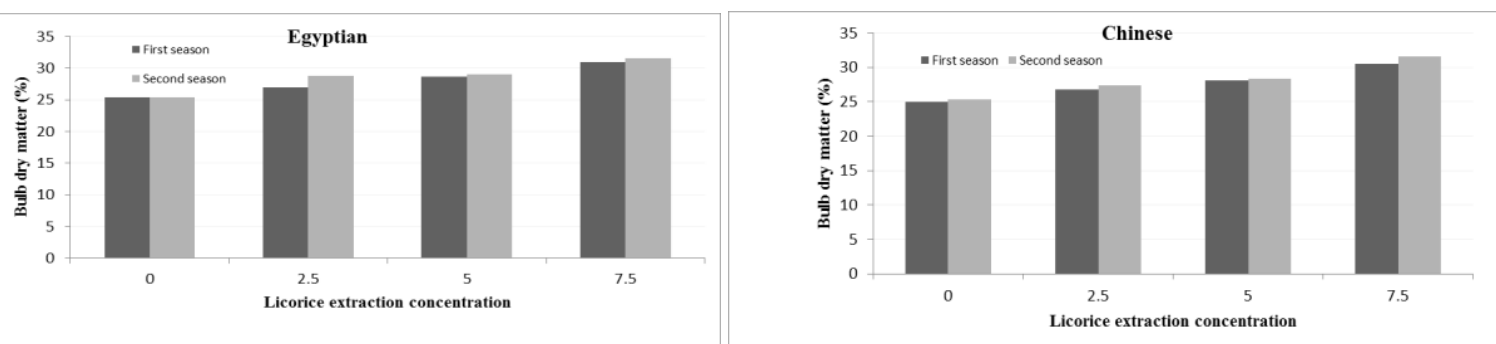

Fig. 8 : Effect of interaction between garlic varieties and licorice root extraction dry matter of garlic plants at harvesting date during winter seasons of 2018/2019 and 2019/2020.


Fig. 9 : Effect of interaction between garlic varieties and licorice root extract bulbing ratio of garlic plants at harvesting date during winter seasons of 2018/2019 and 2019/2020

Table 9A. Effect of garlic varieties and licorice root extract and on total yield during winter seasons of 2018/2019 and 2019/2020.

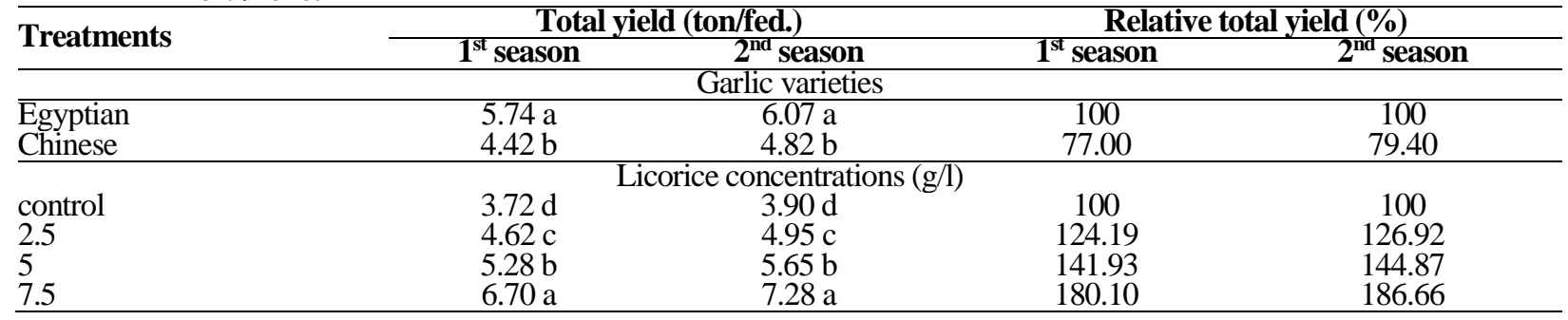

Table 9B. Effect of interaction between garlic varieties and licorice root extract on total yield during winter seasons of 2018/2019 and 2019/2020.

\begin{tabular}{|c|c|c|c|c|c|}
\hline \multirow{2}{*}{ Treatments } & & \multicolumn{2}{|c|}{ Total yield (ton/fed.) } & \multicolumn{2}{|c|}{ Relative total yield (\%) } \\
\hline & & $1^{\text {st }}$ Season & $2^{\text {nd }}$ Season & $1^{\text {st }}$ Season & $2^{\text {nd }}$ Season \\
\hline \multirow{5}{*}{ Egyptian } & & & Interaction & & \\
\hline & control & $4.08 \mathrm{de}$ & $4.18 \mathrm{~d}$ & 100 & 100 \\
\hline & 2.5 & $5.23 \mathrm{c}$ & $5.53 \mathrm{bc}$ & 128.18 & 132.29 \\
\hline & 5 & $6.16 \mathrm{~b}$ & $6.44 \mathrm{~b}$ & 150.98 & 154.06 \\
\hline & 7.5 & $7.50 \mathrm{a}$ & $8.12 \mathrm{a}$ & 183.82 & 194.25 \\
\hline \multirow{4}{*}{ Chinese } & control & $3.36 \mathrm{e}$ & $3.62 \mathrm{~d}$ & 100 & 100 \\
\hline & 2.5 & $4.02 \mathrm{de}$ & $4.38 \mathrm{~cd}$ & 119.64 & 120.99 \\
\hline & 5 & $4.41 \mathrm{~d}$ & $4.86 \mathrm{~cd}$ & 121.48 & 134.25 \\
\hline & 7.5 & $5.90 \mathrm{bc}$ & $6.43 \mathrm{~b}$ & 175.59 & 177.52 \\
\hline
\end{tabular}

3. Total yield( fed) and relative total yield (\%)

The results of yield and its components, i.e., marketable yield, non -marketable yield and total yield (ton/fed.) during 2018/2019 and 2019/2020 seasons are presented in Tables 9 and 10.One Feddan produced 5.74 and 6.07 ton from Egyptian cultivar while the production of were Chinese cultivar 4.42 and 4.82 ton under the conditions of the experiments in the first and second season, respectively as shown in table 9. On the other hand, applying the treatments of the licorice root extract increased garlic total yield values to reach 6.70 and 7.28 ton/fed compared to control (3.72 and 3.90 ton/fed) in the first and second seasons, respectively . For the interaction between garlic cultivars and treating garlic cloves and plants with licorice root extract The best values of total yield/fed were obtained by treating garlic cloves and plants with at concentration $7.5 \mathrm{~g} / \mathrm{L}$ of licorice root extract7.50 and 8.12 ton/fed for Egyptian cultivar and 5.90 and 6.43 ton/fed for the Chinese cultivar in the first and second season, respectively (Table 9) and Fig 10. Regarding the relative total yield, data in the same table showed that soaking garlic cloves before plantation and foliar spraying garlic plants with licorice roots extract with different ascending concentrations increased the relative total yield percentage to reach 180.10 and 186.66 $\%$ with the concentration of $7.5 \mathrm{~g} / \mathrm{L}$ and the increases in total yield were about 80.10 and $86.66 \%$ over control treatment (control) and yield of Chinese cultivar decreased by $13.20 \%$ compared to Egyptian cultivar in the first and second season respectively Table 9(B) and Fig 11.

In general, marketable yield was more than nonmarketable yield of garlic plants. In addition, the highest values for marketable yield and the lowest values for nonmarketable yield were recorded with application of at concentrion $7.5 \mathrm{~g} / \mathrm{L}$ of licorice root extract in both seasons. Treating garlic cloves and plants with licorice roots extract increased the highest values for marketable yield from 2.67 and 2.78(control treatment) to 6.25 and 6.79 (at concentrion7.5 g/L of licorice root extract), Table (10) and Fig 12,13 . 

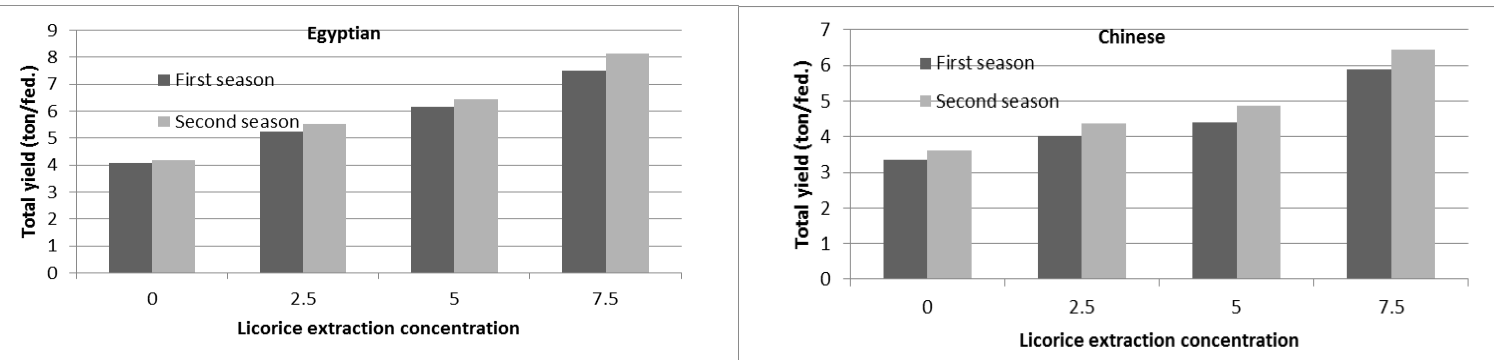

Fig. 10. Effect of garlic varieties and licorice root extract on total yield during winter seasons of 2018/2019 and 2019/2020.
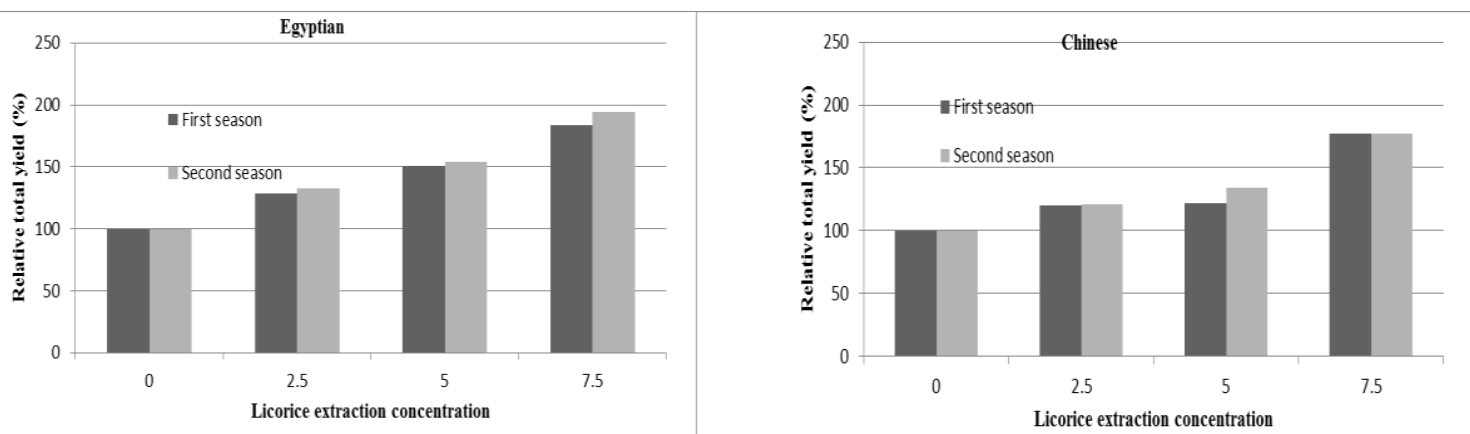

Fig. 11 . Effect of garlic varieties and licorice root extract on Relative total yield during winter seasons of 2018/2019 and 2019/2020.

Table 10A. Effect of garlic varieties and licorice root extract on marketable yield and non-marketable yield during winter seasons of 2018/2019 and 2019/2020.

\begin{tabular}{|c|c|c|c|c|}
\hline \multirow{2}{*}{ Treatments } & \multicolumn{2}{|c|}{ Marketable yield (ton/fed) } & \multicolumn{2}{|c|}{ Non-marketable yield (ton/fed) } \\
\hline & $1^{\text {st }}$ Season & $2^{\text {nd }}$ Season & $1^{\text {st }}$ Season & $2^{\text {nd }}$ Season \\
\hline \multicolumn{5}{|c|}{ Garlic varieties } \\
\hline Egyptian & $5.03 \mathrm{a}$ & $5.32 \mathrm{a}$ & $0.71 \mathrm{a}$ & $0.75 \mathrm{a}$ \\
\hline Chinese & $3.66 \mathrm{~b}$ & $4.00 \mathrm{~b}$ & $0.76 \mathrm{a}$ & $0.81 \mathrm{a}$ \\
\hline \multicolumn{5}{|c|}{ Licorice concentrations $(\mathrm{g} / \mathrm{l})$} \\
\hline control & $2.67 \mathrm{~d}$ & $2.78 \mathrm{~d}$ & $1.05 \mathrm{a}$ & $1.12 \mathrm{a}$ \\
\hline 2.5 & $3.83 \mathrm{c}$ & $4.10 \mathrm{c}$ & $0.80 \mathrm{~b}$ & $0.85 \mathrm{~b}$ \\
\hline 5 & $4.63 \mathrm{~b}$ & $4.98 \mathrm{~b}$ & $0.65 \mathrm{c}$ & $0.67 \mathrm{c}$ \\
\hline 7.5 & $6.25 \mathrm{a}$ & $6.79 \mathrm{a}$ & $0.44 \mathrm{~d}$ & $0.48 \mathrm{~d}$ \\
\hline
\end{tabular}

Table 10B. Effect of interaction between garlic varieties and Licorice root extraction on marketable yield and nonmarketable yield during winter seasons of 2018/2019 and 2019/2020.

\begin{tabular}{lccccc}
\hline \multirow{2}{*}{ Treatments } & & \multicolumn{2}{c}{ Marketable yield (ton/fed) } & \multicolumn{2}{c}{ Non-marketable yield (ton/fed) } \\
\cline { 3 - 6 } & & $\mathbf{1}^{\text {st }}$ season & $\mathbf{2}^{\text {nd }}$ season & \multicolumn{1}{c}{$\mathbf{1}^{\text {st }}$ season } & $\mathbf{2}^{\text {nd }}$ season \\
\hline \multirow{4}{*}{ Egyptian } & control & $3.04 \mathrm{~d}$ & Interaction & $1.04 \mathrm{a}$ & $1.08 \mathrm{a}$ \\
& 2.5 & $4.48 \mathrm{c}$ & $3.10 \mathrm{ef}$ & $0.75 \mathrm{~b}$ & $0.83 \mathrm{~b}$ \\
& 5 & $5.54 \mathrm{~b}$ & $4.70 \mathrm{c}$ & $0.62 \mathrm{bc}$ & $0.62 \mathrm{bc}$ \\
& 7.5 & $7.06 \mathrm{a}$ & $5.82 \mathrm{~b}$ & $0.44 \mathrm{c}$ & $0.47 \mathrm{c}$ \\
\hline \multirow{2}{*}{ Chinese } & control & $2.30 \mathrm{e}$ & $7.65 \mathrm{a}$ & $1.06 \mathrm{a}$ & $0.87 \mathrm{~b}$ \\
& 2.5 & $3.17 \mathrm{~d}$ & $2.46 \mathrm{f}$ & $0.85 \mathrm{ab}$ & $0.73 \mathrm{bc}$ \\
& 5 & $3.73 \mathrm{~d}$ & $3.51 \mathrm{de}$ & $0.68 \mathrm{bc}$ & $0.50 \mathrm{c}$ \\
\hline
\end{tabular}

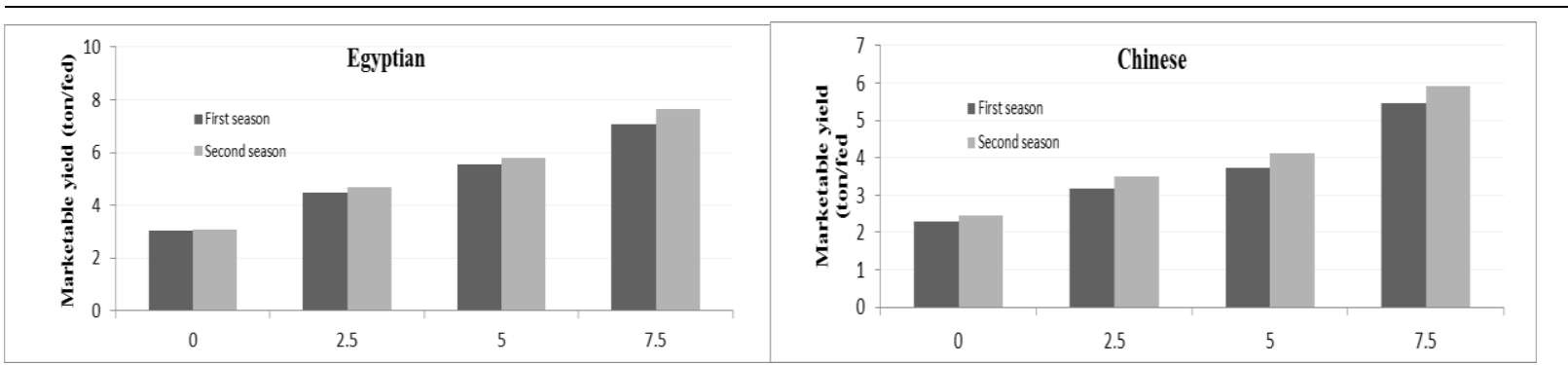

Fig. 12. Effect of interaction between garlic varieties and Licorice root extraction on marketable yield during winter seasons of 2018/2019 and 2019/2020. 

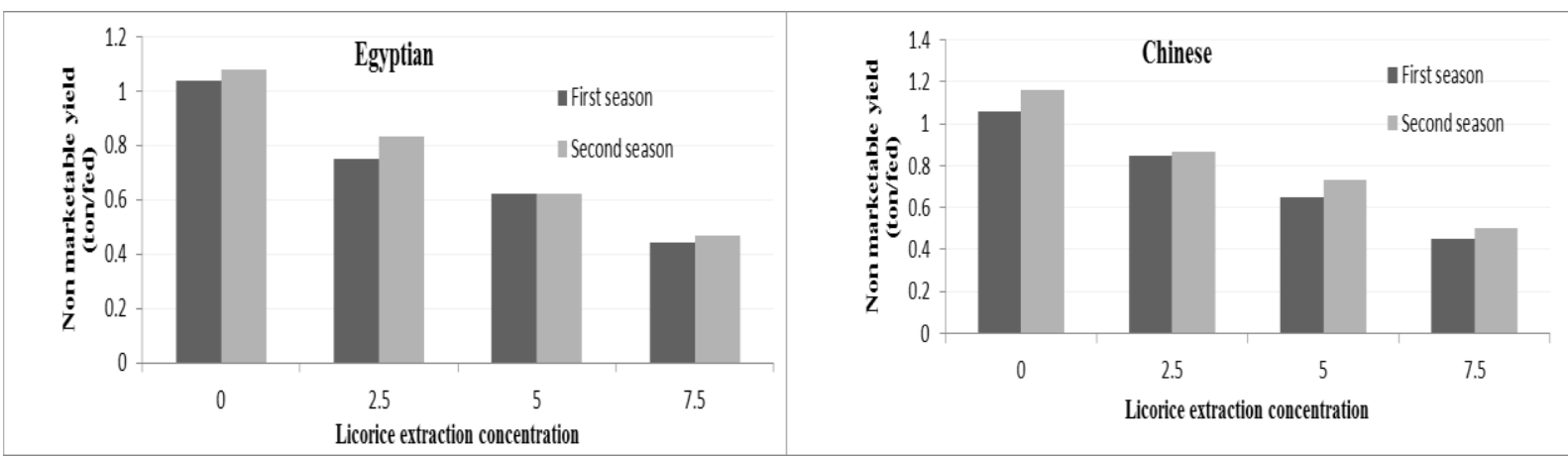

Fig. 13. Effect of interaction between garlic varieties and Licorice root extract on non-marketable yield during winter seasons of 2018/2019 and 2019/2020.

\section{DISCUSSION}

As the Ministry of Agriculture in Egypt is following a new strategy to spread vegetables cultivation in new reclaimed lands this study was conducted in a poor new reclaimed soil in the New Valley governorate to study the effect of garlic cultivars (two different cultivars were used; Egyptian and Chinese) as the first factor and four concentrations of licorice root extract (control , 2.5, 5.0, and $7.5 \mathrm{~g} / \mathrm{L}$ ) were used as the second factor. Results showed that these two cultivars differed in their growth and production behavior under these environmental conditions. The Egyptian cultivar behaved better than the Chinese one as it is good adapted to the Egyptian environment. Most of the recorded data e.g., plant height, plant fresh weight, bulb fresh weight and yield components (total yield, marketable yield, and non-marketable yield) These results are in agreement with those of (Osman and Moustafa 2009; Moustafa, 2011; Gad El-Hak et al., 2011 and 2012; Hammdi and Abbass, 2012; Fathel et al., 2015; Abdel Rasheed et al., 2016 a \& b; Frattaroulo et al., 2019).

As for foliar spraying with natural extracts e.g., licorice root extract many researches showed that spraying onion plants with licorice root extract significantly promoted vegetative growth and bulb production. Other studies reported that spraying forwarded the process of flowering, increased flower set, the number of flowers/umbel, umbel diameter, and production of seeds (Hussein, 2020; Moses et al., 2002; Al-Ajeeli, 2005; Moustafa et al., 2009; Sabry et al., 2009). Licorice extract is rich in amino acids, vitamins and growth stimulating photo-hormones that increases the activity of apical meristem tissue resulting in cell division and elongation (Alabady, 2002; Al-Ajeeli, 2005; Khan et al., 2009; Lazim and Ahmed, 2013). In this study, licorice root extract had significant effects on garlic growth and production along with the quality of obtained bulbs and decreased the percentage of non-marketable bulbs and increased that of marketable bulbs under these conditions of poor newly reclaimed soils. Meanwhile, by using these treatments garlic plantations could be horizontally spread in the New Valley governorate as it is very vast and records about $64 \%$ of total area of Egypt.

\section{CONCLUSION}

These experiments were conducted in a very poor sandy soil of the New Valley located in the South-West of Upper Egypt. This kind of soil is not good for garlic production. But results of this study are very promising as different concentrations of licorice root extract increased garlic plant growth, yield, and yield components along with the chemical compositions of garlic bulbs of both Egyptian and Chinese cultivars. These results can increase the amount and quality of garlic bulbs (green or dry) supposed to be exported abroad.

\section{REFERENCES}

Abdel-Rasheed K.G. Moustafa Y.M.M., Abdel-Ati Y.Y. Gadelhak S.H. (2016a). Traits under laboratory conditions to identify garlic genotypes suitable for organic agriculture. Egypt. J. Agric. Res., 94 (1): 7388.

Abdel-Rasheed K.G. Moustafa Y.M.M., Abdel-Ati Y.Y. Gadelhak S.H. (2016b). Efficacy of genotype selection for yield potentiality in garlic under organic agriculture conditions. Egyptian Journal of Plant Breeding. Egypt. J. Plant Breed. 20(3): 465-492.

Abdul-Jabbar I .M. and M .S. Al-Allaf (2012). Effect of Soil Mulching and Spraying with Licorice Extract and Alga mix on Growth and Production of Lettuce ( Lactuca sativa L. cv.' Paris Island' ). Jordanian Journal of Agricultural Sciences. 8(1): 79- 93.

Alabdaly H. M. S., Effect of some nutrients and GA3 and licorice extract to the growth and the production of flowers and a breakthrough in the cup cloves (Dianthus Caryophyllus L), Ph.D. dissertation, Faculty of Agriculture, University of Baghdad, Iraq, 2002.

Al-Ajeeli T .A.Z. (2005). Effect GA3 and some nutrients to produce Glycyrrhizgin and some other components in the plant Licorice (Glycyrrhiza glabra L.), Ph.D.dissertation, Faculty of Agriculture ,University of Baghdad, Iraq.

AL-Marsoumi H .G.K. (1999a). Effect of some factors in recipes vegetative growth and flowering and holds seed in three varieties of onion (Allium cepa L.), Ph.D.dissertation, Faculty of Agriculture ,University of Baghdad, Iraq.

AL-Marsoumi H. G. K. (1999b). Effect of some factors in recipes vegetative growth and flowering and holds seed in three varieties of onion (Allium cepa L.), Ph.D. dissertation, Faculty of Agriculture, University of Baghdad, Iraq,

Al-Otayk S .M.I., M.I. Motawei and El-Shinawy MZ (2009). Variation in productive characteristics and diversity assessment of garlic cultivars and lines using DNA markers. Journal of Meteorology Environment and Arid land Agriculture Sciences 20:1. 
Amagase H., B.L. Petesch., H. Matsuura., S. Kasuga and Y. Itakura (2001). Intake of garlic and its bioactive components. Journal Nutrition 131: 955-962.

AOAC (2000). Official Methods of Analysis of the AOAC, Association of Official Analytical Chemists, Arlington.

Ata AM (2005). Constitutive heterochromatin diversification of two Allium species cultivated in Egypt. Proc. Afric. Crop Sci. Conf. 7: 225-231.

Babilie R ., B. Abu Trabi ., M. Jbour and R. Murshed (2015a). Effect of Foliar spray with Glycyrrihiza Glabra Root Extract and Gibberellic Acid on Onion (Allium cepa L.) Growth under Water Stress Conditions. Jordan Journal of Agricultural Sciences . Vol. 11. Issue 2: 629-640.

Babilie R., M. Jbour and B. Abu Trabi (2015b). Effect of foliar spraying with licorice root and seaweed extractson growth and seed production of onion (Allium cepa L) . Int J. ChemTeachRes. 8(11) : 557563.

Babilie R., B. Abu Trabi., M. Jbour and R. Murshed (2015c). Response of onion to foliar spray with

Black C .A.(ed.) 1965; Method of Soil Analysis, Part 2, Chemical and Microbiological

Burba J .L and P. Gomez Riera (1997). Characterization, adaptation and selection of garlic germplasm (Allium sativum $\mathrm{L}$.) through the management of dormancy in Mendoza, Argentina. Acta Horticulturae 433: 151164.

Elrys A .S. and A-R. Merwad (2017). Effect of Alternative Spraying with Silicate and Licorice Root Extract on Yield and Nutrients Uptake by Pea Plants Egyptian Journal of Agronomy. 39(3) : 279 - 292.

Etoh T and P.W. Simon (2002). Diversity, fertility and seed production of Garlic In: Rabinowitch, HD and L. Currah (eds), Allium Crop science: Recent advances, CAB International.

Fathel H .B., A.F. Qasim and Th.A. Zhuan (2015). Effects of gibberellic, salicylic acid and liquorice extract in yield , quality flowers carnation and the essential oil content. Tikrit Journal for Agricultural Sciences. 15(1): 31- 46.

Frattaruolo L., G. Carullo., M. Brindisi., S. Mazzotta., L. Bellissimo., V. Rago., R. Curcio., V. Dolce., F .Aiello and A.R. Cappello (2019). Antioxidant and Anti-Inflammatory Activities of Flavanones from Glycyrrhiza glabra L. (licorice) leaf phytocomplexes: identification of licoflavanone as a modulator of nf$\mathrm{kb} / \mathrm{mapk}$ pathway.

Gad El-Hak S. H., Youssef N. S., Moustafa Y.M.M. and Abdelrasheed K.G. (2012). Various Pre-Planting Clove-Seed Treatments Affected Growth, Yield and Storage Quality of Some Colored Garlic (Allium sativum L.) Genotypes. Minia International Conference for Agriculture and Irrigation in the Nile Basin Countries, 26th -29th March 2012: 289-300.

Gadel-Hak S.H., Y.M.M. Moustafa, G. F. Abdel-Naem and I.A. Abdel-Wahab (2011). Studying different quantitative and qualitative traits of some white- and colored garlic genotypes grown under a drip irrigation system. Australian Journal of Basic and Applied Sciences, 5(6): 1415-1427.
Gehan M. Anwar; Rasha K. Helmy; Y.M.M. Moustafa (2016). Assessment of genetic diversity in garlic clones using SSR and ISSR markers. Egypt. J. Genet. Cytol. 45: 333-345.

Gehan M. Anwar; Rasha K. Helmy; Y.M.M. Moustafa (2017). Genetic diversity among some species of the genus Allium L. using SSR and ISSR markers. Egypt. J. Genet. Cytol. 46: 221-233.

Hammdi M .T and J .A. Abbass (2012). Effect of Spraying Zinc and Liquorice (Glycyrrhiza glabra ) Root Extract on Growth and Flower of Spanish Iris( Iris xiphium L. ). Bulbs. Jordanian Journal of Agricultural Sciences. 8(1): $127-137$.

Hussein W.A. (2002). Effect of garlic and licorice extracts and urea on vegetative and flowering growth, yield and qualitative characters of cucumber. M.Sc.Thesis. College of agriculture. University of Baghdad. Iraq.

Iciek M., I. Kwiecien and L. Wlodek (2009). Biological properties of garlic and garlic-derived organosulfur compounds. Environmental and molecular mutagenesis 50: 247-265.

Jabbes N., A.Ingrid., A. Jacques., Al MD Bouthaina and H. Cherif (2012). Agro-morphological markers and organo-sulphur compounds to assess diversity in Tunisian garlic landraces. Scientia Horticulturae.148: 47-54.

Khan H., M.M. Hussain., G. Jellani., S.T. Hidayatullah., T. Naseeb., S. Mhmood (2018). Evaluation of Garlic Genotypes for Yield and Yield Components in Islamabad, Pakistan Environment. The Nucleus 55(1) :22-26.

Khan W., Rayirath U. P., Subramanian S., Jithesh M. N., Rayorath. P., Hodges D .M., Critchley A.T., Craigie J. S., Norrie J. and Prithiviraj B. (2009). Seaweed extracts as biostimulants of plant growth and development, J. Pl. Growth Regul. 28: 386-399.

Lazim Z .S and Z .M. Ahmed (2013). The effects spray applications of dry yeast suspension and liquorice root extracts on the vegetative and tubers growth characteristics of wild orchid Anacamptis coriophora. Al Furat Journal of Agricultural Sciences. 5(3) : 2833.

Matr H .M., S. Mahmoud and A.F.R. Ramadan (2012). Effect of the treatment by gibberelic acid and liquorice extract on growth and yield of potato. Diyala Journal of Agricultural Sciences. 4(1) : 220- 234.

Moses T. N., Abdul-Jabbar W. A. and Elwy A. N., A study of some local licorice root powder components (Glycyrrihiza glabra L.), The Iraqi Journal of Agricultural Sciences, 2002, 33(4):30-38.

Moustafa Y.M.M. (2011). Pre-planting clove chilling enhanced the selection program of introduced garlic (Allium sativum L.) cultivars under a drip irrigation system. Minia J. Agric. Develop. Sci. 3(1): 49-66.

Moustafa Y.M.M., S.S. Latif, G.F. Abd El Naem, H.M.H. Fouly and S.I. Ahmed (2009). Performance of new imported foreign garlic genotypes grown under the Egyptian conditions. Egypt. J. Agric. Res., 87 (1): 219- 243 . 
Osman S-A and Y.M.M. Moustafa (2009). Horticultural and cytogenetical characteristics of some Egyptian and foreign garlic cultivars. African Crop Science Conference Proceedings, African Crop Science Society. Vol. 9. pp. $459-465$.

Page A .L.(ed.) 1982; Method of Soil Analysis, Part 2, Chemical and MicrobiologicalProperties, Second edition, American Society of Agronomy, Inc and Soil ScienceSociety of America, Inc., Publisher, Madison, Wisconsin USA.

Pandey UB . (2012). Garlic, Handbook of herbs and spices, Woodhead Publishing.

Properties, American Society of Agronomy, Inc, Publisher, Madison, Wisconsin USA.

Research (GCSAR), Damascus, Syria. 31(1) : 159 - 169.

Sabry G. H., Mervat S. and Abd EL-Wahba M. A., Influence of effective micro-organism, seaweed extract and amino acids application on growth, yield and bunch quality of Red Globe grapevines, J. Agric. Sci. Mansoura Univ., 2009, 34, 5901-5921. seaweed extract and GA at different irrigation levels. General Commission for Scientific Agricultural

Shalaby A .T and H . El-Ramady (2014). Effect of foliar application of bio-stimulants on growth, yield, components, and storability of garlic (Allium sativum L.). AJCS. 8(2): 271-275.

Sterling S .J and D.R. Eagling (1997). Agronomics and allicin yield of Australian grown garlic (Allium sativum), 2nd Int. Symp. on Edible Alliaceae 555: 63-73.

Tsai C .W., Chen H.W., Sheen L.Y and C.K. Lii (2012). Garlic: Health benefits and actions, Bio Medicine 2:17-29.

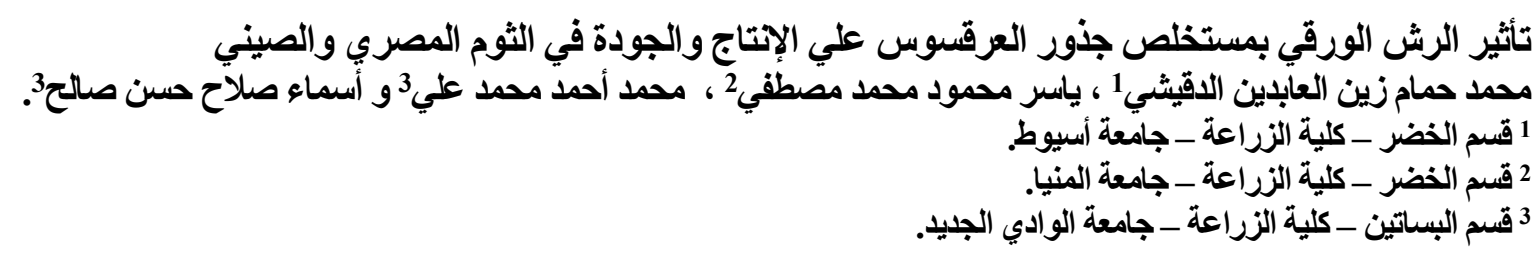

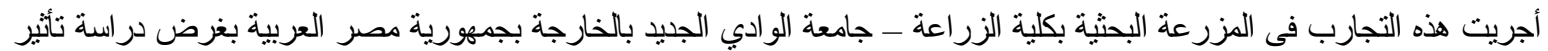

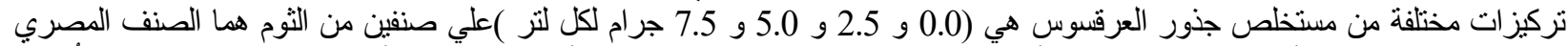

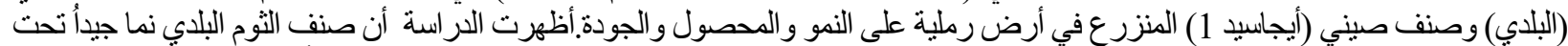

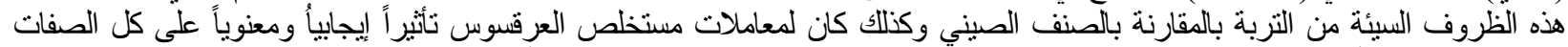

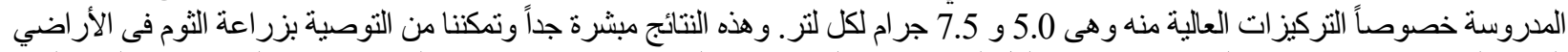

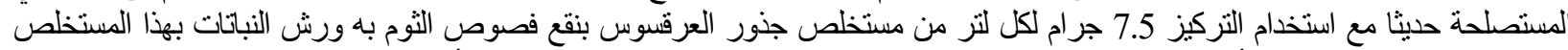

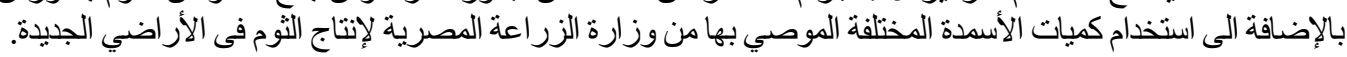

